\section{Crossing over}

\section{J. Arnemann}

Abteilung Molekulargenetik, Labor Dr. Wisplinghoff, Köln, Deutschland

Synonym(e) kreuzweise Überlagerung

Englischer Begriff crossing over

Definition Crossing over ist ein Ereignis der Meiose und beschreibt die kreuzweise Überlagerung von paternalen und maternalen Chromatiden mit nachfolgender Rekombination.

Beschreibung Im Zygotänstadium der Prophase I der Meiose bildet sich der synaptonemale Komplex aus. Diese komplexe Proteinstruktur ist daran beteiligt, dass sich die väterlichen und mütterlichen Chromosomen aneinanderlegen, miteinander paaren und dabei Bivalente ausbilden. In der Folge kommt es zu kreuzweisen Überlagerungen der Nicht-Schwesterchromatiden. Hierbei kommt es zu Brüchen in der Doppelhelix und die mütterlichen und väterlichen Enden werden wechselweise physisch verknüpft, was als Chiasmata bezeichnet wird. Es kommt somit zu zahlreichen Neukombinationen von mütterlicher und väterlicher DNA (intrachromosomale Rekombination). Als Folge sind die Gameten genetisch heterogen und vereinen Eigenschaften des väterlichen und mütterlichen Genoms.

\section{Literatur}

Alberts et al (2002) Molecular biology of the cell, 4. Aufl. Garland Science, New York 